\title{
The Potency Purple Sweet Potato (Ipomoea batatas) Leaf Extract as Biofungicide for Controlling Fusarium Rot on Chili
}

\author{
Dina Dyah Saputri ${ }^{1}{ }^{*}$, Annisa Wulan Agus Utami ${ }^{2}$ \\ ${ }^{1}$ Faculty of Teacher and Training Education, University of Pakuan, Bogor 16143, Indonesia \\ 2 Faculty of Mathematics and Science, State University of Jakarta (UNJ), Jakarta 13220, Indonesia
}

Article history:

Submission January 2020

Revised April 2020

Accepted May 2020

*Corresponding author:

E-mail:

dinadyahsaputri@gmail.com

\begin{abstract}
Fusarium sp. has been recognized as a pathogenic agent causing fruit rot in chili. The disease significantly decreases the annual chili production rate. One of the plants potentially utilized as biofungicide to control Fusarium fruit rot disease in chili is purple sweet potato (Ipomoea batatas L.). Purple sweet potato contains secondary metabolites, mainly the active compounds in the form of flavonoids, which has been previously revealed to perform antifungal activity. This study aimed to examine the potential of purple sweet potato (Ipomoea batatas L.) leaf extract as biofungicide to inhibit the growth of chili rot disease caused by Fusarium sp. within vitro and in vivo assay. This work was conducted by testing the ethanol-extracted purple sweet potato leaves extracts against Fusarium sp. with various concentrations, i.e., 5\%, 10\%, 20\%, and $40 \%(\mathrm{w} / \mathrm{v})$ for in vitro assay. Then antifungal test against Fusarium sp. was conducted using preventive and curative test for in vivo assay. Observations were performed for 7 days. The result of in vitro assay showed inhibitory ability of the leaves extract against the growth of Fusarium sp. to range between $35.2-76.6 \%$ with potential concentration $40 \%(\mathrm{w} / \mathrm{v})$. Based on the results of in vivo assay, the preventive test using $40 \%$ concentration of purple sweet potato leaves extract showed significant different against negative control through Duncan test $(\alpha=0.05)$. Purple sweet potato leaves extract with $40 \%$ concentration can reduce the intensity of Fusarium fruit rot disease and potentially utilized as biofungicide.
\end{abstract}

Keywords: biofungicide, chili, Fusarium, Ipomoea batatas

\section{Introduction}

Fusarium has been recognized as a pathogenic fungus causing wilt and fruit rot. In Bogor, Indonesia, Fusarium sp. had been isolated as the cause of wilting of leaves on infected chili plants in various villages (Utami, 2018). The disease resulted in reduced chili production, reaching $30-40 \%$ below normal production levels (Pandey \& Gupta, 2013). Hence, efforts to increase chili production yields could begin with the use of fungicides to inhibit the growth of Fusarium sp. at chili plants. However, continuous uses of synthetic fungicides in a long period had expectedly been causing a disturbed ecological balance (Tando, 2018). Biofungicide, therefore, has been as an alternative to control the disease by offering various advantages, including environmentally friendly characteristics, high degradability, abundant in nature, and line with the concept of sustainable agriculture (Dalimunthe \& Rachmawan, 2017).

Among others, purple sweet potato (Ipomoea batatas L.) has been considered as a potential biofungicide. Purple sweet potato contains the highest anthocyanin content $( \pm 110.51$ $\mathrm{mg} / 100 \mathrm{~g}$ ) higher compared to other types of purple sweet potatoes. Anthocyanin is a secondary metabolite of flavonoids and polyphenols, which have been recognized to act as an antioxidant (Ginting et al., 2011). Extracting of purple sweet potato leaves by applying ethanol solvent has discovered secondary metabolites

\section{How to cite:}

Saputri DD, Utami AWA (2020) The potency of purple sweet potato (Ipomoea batatas) leaf extract as biofungicide for controlling Fusarium fruit rot on chili. Journal of Agriculture and Applied Biology 1 (1): 1 - 8. doi: 
in the forms of alkaloids, steroids-triterpenoids, saponins, tannins, and flavonoids (Saputri \& Kurniasih, 2018). Another research on an ethanol extract of purple sweet potato leaves has further revealed its potential as an inhibiting agent to the growth of Fusarium sp. (Saputri, 2018). In chili plants, the applications of bio fungicides are currently limited in laboratory uses only and have not reached public releases in the form of commercial products. Therefore, strategic steps in bio fungicide researches are required to explore the practical uses of purple sweet potato leaves, which have been experimentally proven to inhibit the growth of Fusarium sp. in general, on chili plants. Purple sweet potato leaf is particularly chosen due to its abundant presence in Indonesia, especially in the Bogor area. Its current utilization, however, has not been taken to its optimum potentials, in which the leaves are currently been used only as animal feeds. It is a contrast to the discovery of metabolites of sweet potato extract that perform bioactivity as antifungal agents. This study was aimed to determine the potency of purple sweet potato (Ipomoea batatas L.) leaves as a biofungicide for inhibiting the growth of Fusarium sp. causal agent of chili fruit rot.

\section{Material and Methods Purple Sweet Potato Leaves Extraction}

Samples of purple sweet potato leaves used in this study were obtained from a farm in Bogor, West Java, Indonesia. In this step, ethanol $70 \%$ was taken as a solvent. Samples were macerated with the solvent in a 1:10 ratio at room temperature for 5 days. Next, the macerated samples were filtered. The filtrate was later evaporated in a rotary evaporator IKA RV6 at $60{ }^{\circ} \mathrm{C}$ to evaporate, resulting in a concentrated extract. Then, the concentrated extract was weighed to measure the extract yield of maceration.

\section{Fusarium sp. Regeneration}

Fusarium sp. was rejuvenated by etching it using an inoculating loop (one needle) on a sloping medium (Berlian et al., 2016). Then, it was incubated at room temperature for 7 days (Setyaningsih et al., 2012).

\section{Preparation of Extracts Concentration}

Extracts concentration of purple sweet potato were made by dissolving previously concentrated extract with DMSO 10\% solvent at various concentrations, i.e., $5 \%, 10 \%, 20 \%$, and $40 \%(\mathrm{w} / \mathrm{v}$ ) (Hidayati \& Harjono, 2017).

\section{In Vitro Assay of Purple Sweet Potato Leaf Ex- tract Against Fusarium sp.}

Furthermore, in vitro assays of ethanol-extracted purple sweet potato leaves on the growth of Fusarium sp. were performed on PDA mediums aseptically. Each extract was mixed with liquid PDA to form the medium with a specific sweet potato extract concentration of 5\%, $10 \%, 20 \%$, or $40 \%$. Furthermore, isolates of Fusarium sp. in $5 \mathrm{~mm}$ diameter were grown on all test media. As a negative control, Fusarium sp. isolates were grown on a non-extract-added PDA medium, which was without the addition of purple sweet potato leaves extract. For positive control, isolates of Fusarium sp. were also grown on a non-extract-added PDA medium mixed with a Propineb $70 \%$ fungicide at $0.2 \%$ concentration $(\mathrm{w} / \mathrm{v})$. Each in vitro test treatment was repeated 5 times.

\section{In Vivo Inhibition Assay}

In vivoinhibition assays of purple sweet potato leaf extract with $40 \%$ concentration were conducted in curative and preventive tests. A curative test was performed to determine the ability of purple sweet potato leaf extract to suppress the incidence of chili rot disease after Fusarium sp. attack. Curative treatment was performed after the first symptoms arose and seven days after the fruit rot. Rot chili fruits were soaked in purple sweet potato leaf extract suspension for 10 minutes, dried, placed on the tray, and subsequently incubated for 7 days. As a negative control, chilis were incubated without soaking in the purple sweet potato leaf extract. A preventive test was performed to determine the potency of purple sweet potato leaf extract to prevent Fusarium infection in chili. The purple sweet potato leaf extract was applied before rot chili disease symptoms appeared. 


\section{Results and Discussion}

In vitro assays of purple sweet potato leaves ethanol extract on the growth of Fusarium sp. The negative control group was observed to show a weak inhibitory ability. Meanwhile, treatment groups with $5 \%, 10 \%$, and $20 \%$ added purple sweet potato leaves extract were observed to deliver a strong inhibitory ability. Then, the application of purple sweet potato leaves extracts at $40 \%$ concentration was observed to perform a very strong inhibitory ability (Table 1). It followed an existing classification of inhibitory ability that suggested the ability of fungal response to growth as weak ( $>3 \mathrm{~cm}$ diameter), medium $(2-3 \mathrm{~cm})$, strong $(1-2 \mathrm{~cm})$, or very strong $(<1 \mathrm{~cm})$ (Alfian et al., 2015).

Based on Table 2, the Duncan-based statistical test with a $5 \%$ significance level discovered the treatment of purple sweet potato leaves extracts at $40 \%$ concentration to be significantly different compared to other treatments. It revealed treatments at all extract concentrations $(5 \%, 10 \%, 20 \%, 40 \%)$ to deliver considerably good inhibitory influences on the growth of Fusarium sp. Table 1 presents the results of the influence of purple sweet potato leaf extract on the growth of Fusarium sp. After that, the percentage of inhibitory ability for each treatment group was calculated (Table 2).

Table 1. Diameter $(\mathrm{cm})$ of Fusarium sp. under various treatments of purple sweet potato leaf extract concentration

\begin{tabular}{cccc}
\hline \multirow{2}{*}{ Treatment } & \multirow{2}{*}{ Average } & Duncan Test $_{0.05}$ & Inhibition Ability \\
\cline { 3 - 4 } & & & \\
\hline $40 \%$ & 0.62 & a & Very Strong \\
\hline $20 \%$ & 1.04 & b & Strong \\
\hline $10 \%$ & 1.18 & b & Strong \\
\hline $5 \%$ & 1.24 & b & Strong \\
\hline Control $(+)$ & 2.14 & c & Medium \\
\hline Control $(-)$ & 3.62 & d & Weak \\
\hline
\end{tabular}

Note numbers followed by the same alphabet refer to insignificances according to the Duncan test at the 5\% significant level. Propineb $70 \%$ as control positive and no treatment as control negative

Tabel 1 shows that purple sweet potato leaves extract at $40 \%$ concentration best decreased significantly the growth of Fusarium sp. compared to other treatments, including positive control. It revealed that treatments at all extract concentrations (5\%, 10\%, 20\%, $40 \%$ ) to deliver considerably good inhibitory influences on the growth of Fusarium sp. Table 1 presents the results of the calculation. After that, the percentage of inhibitory ability for each treatment group was calculated in Table 2.

Table 2. The percentage of the inhibitory ability of purple sweet potato leaves extract against Fusarium sp.

\begin{tabular}{ccccccccc}
\hline \multirow{2}{*}{ Treatment } & \multicolumn{7}{c}{ Inhibition ability after the 7-day treatment period } \\
\cline { 2 - 9 } & $\mathbf{1}$ & $\mathbf{2}$ & $\mathbf{3}$ & $\mathbf{4}$ & $\mathbf{5}$ & $\mathbf{6}$ & $\mathbf{7}$ & $\begin{array}{c}\text { Average } \\
\text { (\%) }\end{array}$ \\
\hline Control (-) & 0 & 0 & 0 & 0 & 0 & 0 & 0 & 0 \\
\hline Control $(+)$ & 11.5 & 21.8 & 30.8 & 38.8 & 48.3 & 48.3 & 46.9 & 35.2 \\
\hline $5 \%$ & 1.9 & 47.0 & 58.8 & 65.6 & 73.5 & 73.5 & 76.5 & 56.7 \\
\hline $10 \%$ & 21.2 & 39.6 & 55.4 & 67.8 & 76.0 & 75.6 & 77.9 & 59.1 \\
\hline $20 \%$ & 39.4 & 42.6 & 58.1 & 69.6 & 78.6 & 78.6 & 80.9 & 64.0 \\
\hline $40 \%$ & 44.2 & 66.8 & 78.5 & 82.9 & 87.4 & 87.2 & 89.2 & 76.6 \\
\hline
\end{tabular}


Based on the result which has shown in Table 2 , the average inhibitory abilities of purple sweet potato leaves extract on the growth of Fusarium sp. by in vitro tests were discovered to range between $56.7-76.6 \%$. Technically, the potentials of purple sweet potato leaves extract as a bio fungicide were measured from the inhibited growth of Fusarium sp. due to the addition of purple sweet potato leaves extract. Observations of in vitro test results on growing media indicated the addition of leaves extracts at $40 \%$ concentration to be more effective in inhibiting the growth of Fusarium sp., resulting in the highest inhibition percentage at $76.6 \%$ compared to other treatment groups.

At $40 \%$ concentration of the leaves extract, the inhibitory ability was observed as being able to diffuse very well, resulting in the opti- mum diffusion of leaves extract into the growing medium containing Fusarium sp (Figure 1). It was observed to produce an increasingly inhibited growth of Fusarium sp., which would be highly desired for horticulture plants infected by the disease (Dani \& Rosmaiti, 2015). Fusarium caused fruit rot had been consistently taking attention as the most common disease found in chili during peak harvest season in various areas in Bogor, Indonesia (Utami, 2018). It had particularly been observed to attack if a chili storage system was not good enough to prevent the growth and spread of Fusarium (Riansyah et al., 2015). It could then cause significant economic losses due to unusable harvested chili. In general, Fusarium fruit rot disease in chili plants could reduce chili production by $30-40 \%$ (Pandey \& Gupta, 2013).

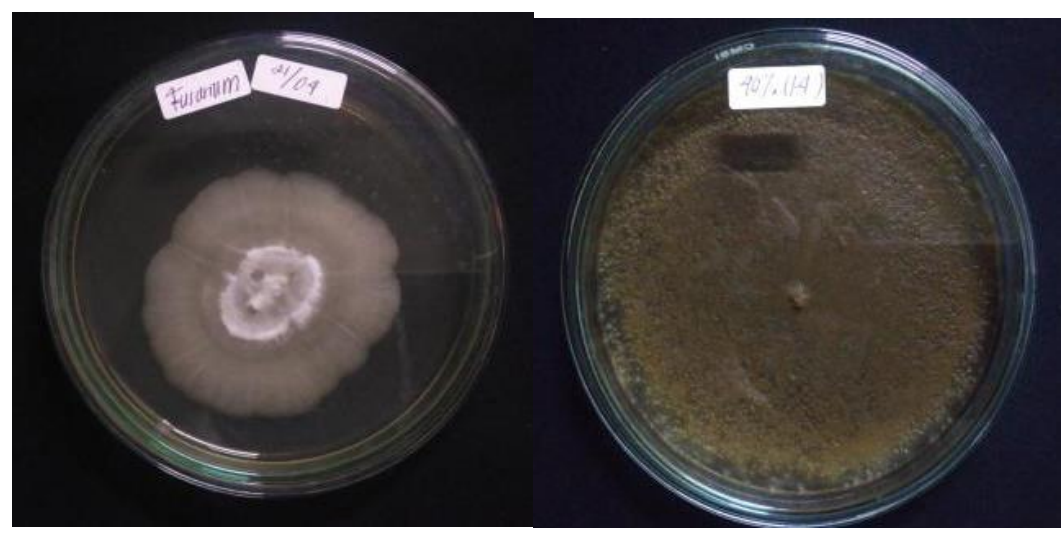

Figure 1. Antifungal activity under optimum conditions (a) 0\% (Negative control), (b) 40\% Ipomoea batatas L. leaves extract to inhibit Fusarium sp. within vivo assay

In general, the uses of chemical fungicides had been stated to affect the conditions of soil, water, treated agriculture products, and human users of these fungicides, hence causing further problems such as unbalanced ecosystems (Riansyah et al., 2015). Therefore, the uses of biofungicide had been stated to act as an alternative treatment in controlling diseases in plants. Biofungicide offered several advantages, i.e., being environmentally friendly, easily degraded, abundant in nature, and line with the concept of sustainable agriculture (Dalimunthe \& Rachmawan, 2017). One of the potential plants to be used as material for controlling Fusarium fruit rot disease is a purple sweet potato plant.
Purple sweet potato leaves can be used as an antifungal because they contain anthocyanin compounds, which are secondary metabolites of flavonoid and polyphenol groups (Berlian et al., 2016). Plants have a natural defense mechanism against pathogen infections by producing compounds such as peptides, protein, flavonoids, and other organic compounds (Soekarno et al., 2012). As an antifungal, flavonoid and phenol can damage pathogenic cell membranes, resulting in changes in cell growth or deaths of fungal cells. These compounds can also desaturate pathogenic cell proteins and shrink cell walls to then lyse fungal cell walls. Besides, flavonoid compounds and phenols can diffuse into fungal cell membranes and disrupt 
metabolic pathways in fungi, including the synthesis of ergosterol, glucans, chitin, proteins, and glucosamine. The compounds will bind with ergosterol, which is a constituent of fungal cell membranes, causing the formation of a pore in the cell membranes. Then, the formed pores cause fungal cell components, i.e., amino acids, carboxylic acids, inorganic phosphates, and phosphates esters, out of the cells to eventually cause fungal cell deaths (Muthukumaran Et al., 2011).

\section{Ipomoea batatas L. Leaves Extract to Inhibit Fusarium sp. within vivo assay}

Ipomoea batatas L. leaves extract to inhibit Fusarium sp. within vivo assay incubation period is the time required for Fusarium sp. to cause the first symptoms on chili after inoculation. Resistant induction influence test on $40 \%$ purple sweet potato leaf extract was capable of expanding the rot disease caused by Fusarium compared to other treatments (Figure 2).

Resistant induction influence preventive test could expand the incubation period of Fusarium rot disease better than positive control as there were fruit rot symptoms that emerged on the 5th day of incubation. Residual influence preventive test could expand the incubation period Fusarium rot disease compared with the positive control using a propineb fungicide. The curative test could suppress Fusarium growth better than the negative control, proven that a $40 \%$ concentration of purple sweet potato leaf extract is potentially utilized as biofungicide (Figure 2).

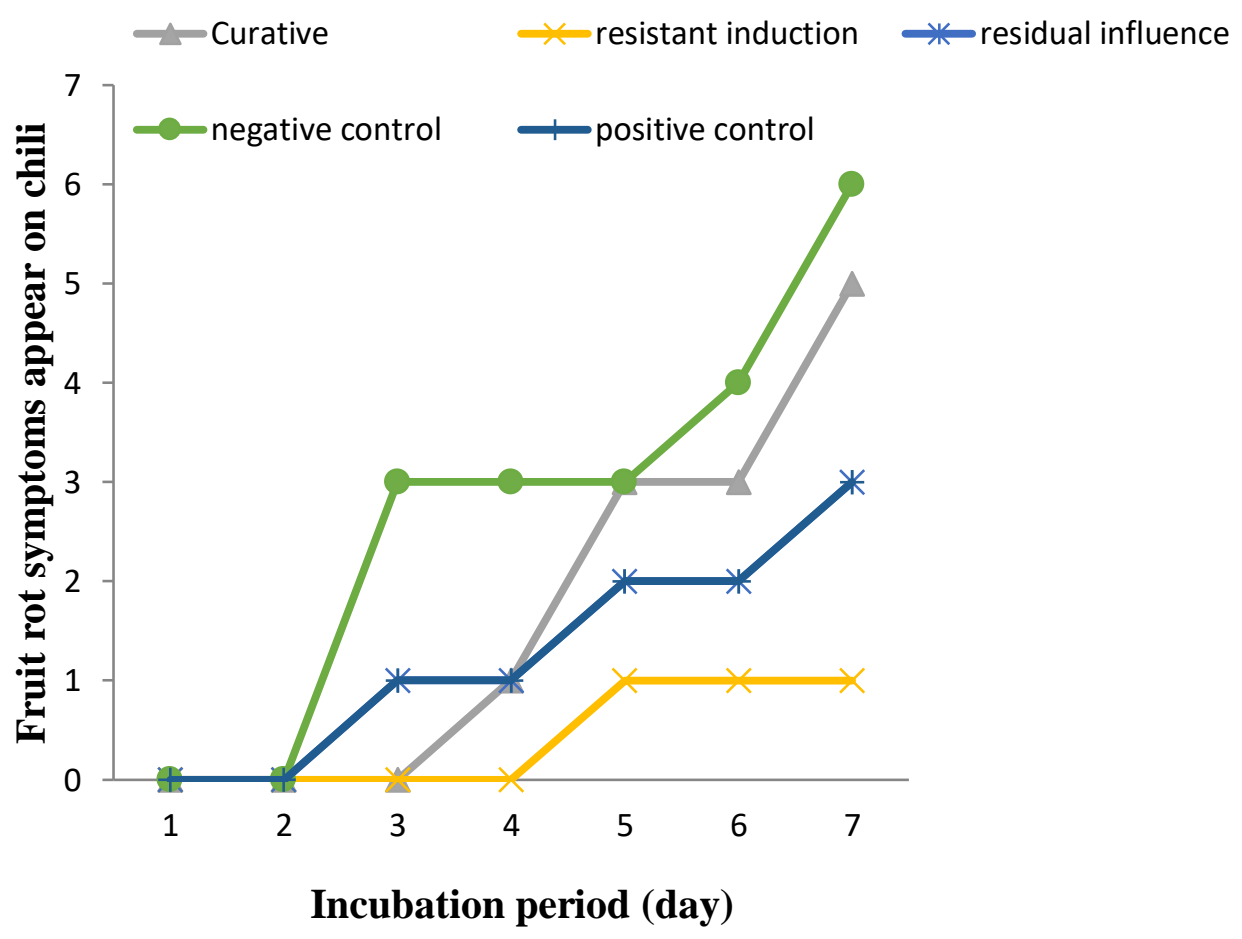

Figure 2. The incubation period for Fusarium sp. to cause the first symptoms on chili

Purple Sweet Potato Leaf Extract Influence on Disease Incidence and Intensity

Based on this study, the most severe disease occurred on the negative control treatment, while the least occurred on resistant induction influence treatment. Duncan's statistical test with $5 \%$ significant degree indicated that resistant induction influence treatment did not 
differ significantly against the residual influence and positive control. The curative test showed no significant difference in the negative control. Disease incidence on preventive treatment of resistant induction and residual influence differed significantly with negative control and did not differ significantly with positive control using $b$ (Table 3). This indicates that rot disease Fusarium growth in chili can be suppressed due to resistant induction and residual influence. Preventive treatment with resistant induction and residual influence decrease disease intensity compared to negative control (Table 4).

Table 3. Purple sweet potato leaf extract with $40 \%$ on disease incidence of rot disease Fusarium using preventive and curative test

\begin{tabular}{cc}
\hline Treatment & Disease Incidence (\%) \\
\hline Resistant induction & $2.23 \mathrm{a}$ \\
\hline Residual influene & $6.67 \mathrm{ab}$ \\
\hline Positive control & $6.67 \mathrm{ab}$ \\
\hline Curative test & $11.09 \mathrm{bc}$ \\
\hline Negative control & $13.30 \mathrm{c}$ \\
\hline
\end{tabular}

*Numbers followed with different letters indicate significant difference (Duncan test $\alpha=0.05$ ).

Table 4. Purple sweet potato leaf extract with $40 \%$ on disease severity of Fusarium rot disease using preventive and curative test

\begin{tabular}{cc}
\hline Treatment & Disease Severity (\%) \\
\hline Resistant induction & $0.43 \mathrm{a}$ \\
\hline Residual influence & $1.33 \mathrm{a}$ \\
\hline Positive control & $1.33 \mathrm{a}$ \\
\hline Curative test & $3.99 \mathrm{~b}$ \\
\hline Negative control & $5.33 \mathrm{~b}$ \\
\hline
\end{tabular}

* Numbers followed with different letters indicate significant difference (Duncan test $\alpha=0.05$ ).

Fusarium rot disease attack chili during the abundant harvest season. This disease affects whether the unwell storage system performs, encouraging the growth and dissemination of Fusarium (Soekarno et al., 2012). Fusarium fungus enters the vessel tissue through root tissues and subsequently uses xylem vessel as a way to rapidly form colonies in the plant, causing typical rot symptom (Wongpie \& Lomthaisong, 2010).

Rot disease caused by F. oxysporum often encounters in chili. This disease plays an important role to reduce chili production (Nurzannah et al., 2014). Efforts to increase chili production can be performed using Fusarium sp. fungicide in chili. However continuous use of synthetic fungicides over long period will cause disrupted ecological balance. Biofungicide utilization becomes an alternative disease control in plant. Biofungicide is environmentally friendly, easily degraded, abundant local resources, and following sustainable agriculture concept (Dalimunthe \& Rachmawan, 2017).

One plant that is abundant and potentially developed as biofungicide is purple sweet potato (I. batatas L.). Purple sweet potato has the highest content of anthocyanins among other types of purple sweet potato, i.e 110.51 $\mathrm{mg} / 100 \mathrm{~g}$. Anthocyanins are secondary metabolite of flavonoids and polyphenols act as antioxidants (Ginting et al., 2011). Purple sweet potato leaf ethanolic extract has been proven to be capable of inhibiting Fusarium sp. growth (Saputri, 2018). Purple sweet potato leaf ethanolic extract contains secondary metabolites, namely flavonoids and tannins, with relatively higher antioxidant activity than alpha tocopherols which are popular as antioxidant compounds (Sulastri et al., 2013). The highest compounds detected in purple sweet potato leaf 
ethanolic extract through Gass Chromatography - Mass Spectrometer (GC-MS) analysis are 1,4-benzenediol (CAS) hydroquinone with $19.70 \%$ concentration (Saputri \& Kurniasih, 2018). 1,4-Benzenediol (CAS) hydroquinone is phenolic compound group with $\mathrm{C}_{6} \mathrm{H}_{6} \mathrm{O}_{2}$ chemical formula (National Chemical Inventories (NCI), 2007). Phenol is bioactive compound as an antibacterial in medicinal herbs (Proestos et al., 2005).

Plants have defense mechanism against pathogenic infection attack by producing compounds, such as peptides, proteins, flavanoids, and other organic compounds (Muthukumaran et al., 2011). Secondary metabolite compounds defend the plants from less favorable environmental conditions, e.g. capable of overcoming pest and disease attack, attracting pollinators, and producing molecular signal. Secondary metabolites are used in organisms to interact with the environment (Putri et al., 2014). Purple sweet potato have athocyanins as antimicrobial agents in foods. The anthocyanins from purple sweet potato (APSP) against the fungal growth of Geotricum candidum and Candida albicans (Wen et al., 2016).

The results, including preventive test both on resistant induction and residual influence and curative test indicates the capability of suppressing Fusarium rot disease intensity better than the negative control. This was shown as lower disease incidence rate than negative control. Based on the study results, purple sweet potato leaf extract is capable of suppressing growth and expansion of Fusarium sp. in chili.

\section{Conclusion}

Extracts of purple sweet potato leaves inhibited the growth of Fusarium sp. The peak inhibition rate was observed to reach $76.6 \%$. In particular, the addition of purple sweet potato leaves extract at $40 \%$ concentration was observed to potentially act as a high performance and environmentally friendly bio fungicide to control Fusarium fruit rot disease on chili plants.

\section{Acknowledgment}

The authors would like to thank to the Faculty of Teacher Training and Education, the University of Pakuan, Indonesia, for providing facilities required in conducting this research. This work was financially supported by the Ministry of Research, Technology and Higher Education (Kementrian Riset, Teknologi \& Pendidikan Tinggi - Ristekdikti), the Republic of Indonesia, through the DIKTI Competitive Research funding program in 2019 fiscal year with grant no. 7/E/KPT/2019 and aggreement or contract no. 110/SP2H/LT/DRPM/2019, 2654/L4/PP/2019, 02/LPPM-UP/KPPDP/III/2019.

\section{References}

Alfiah, R. R., Khotima, S., \& Turnip, M. (2015). Activities of methanol extract of Sambung Rambat (Micrania micrantha Kunth) on Candida albicans fungus growth. Protobiont Journ., 4 (1), 53. Retrieved from http://jurnal.untan.ac.id/index.php/iprb/article/view/8735

Berlian, Z., Aimi, F., \& Lestari, W. (2016). Antifungal activity Ocimum americanum L. leaf extract against Fusarium oxysporum Schleect. Biota Jurnal, 2 (1): 1-9. Retrieved from https://biota.ac.id/index.php/jb

Dalimunthe, C. I., \& Rachmawan, A. (2017). Prospects of utilization of plant secondary metabolites as vegetable pesticides for control of pathogens in rubber plants. Warta Perkaretan, 36 (1): 15-28. doi: 10.22302/ppk.wp.v36i1.324

Dani, J., \& Rosmaiti. (2015). The effect of concentration and duration of soaking colchicine on watermelon (Citrullus lannatus) seeds on plants diversity. Jurnal Penelitian Agrosamudra, 2, (2), 10-18.Retrieved from https://ejurnalunsam.id/index.php/jagrs/article/view/306

Ginting, E., Utomo, J. S., Yulifianti, R., \& Jusuf, M. (2011). Potential of purple sweet potato as functional food. Food Crop Science and Technology, 6(1): 116-138.

Hidayati, A. S., \& Harjono. (2017). Antibacterial activity test of Babadotan (Ageratum conyzoides L.) leaf extract cream in ethanol solvent. MIPA Journal, 4 (1), 1-8. Retrieved from https://journal.unnes.ac.id/nju/index.php/JM

Muthukumaran, P., Padmapriya, P., Salomi, S., Umamaheswari, R., Kalaiarasan, P., \& Malarvizhi, C. (2011). In Vitro antimicrobial activity of leaf powder. Asian Journal of Pharmaceutical Research, 1 (4), 108-110. Retrieved from https://asianjpr.com/

National Chemical Inventories (NCI). (2007). https://www.cas.org/products/nci-global (Accessed on 29 July 2018).

Nurzannah, S. E., Lisnawati., \& Bakti, D. (2014). Online Journal of Agroecotechnology, 2(3), 1230 - 1238. Retrieved from https://www.neliti.com/journals/jurnal-agroekoteknologi-universitas-sumatera-utara 
Pandey, K. K., \& Gupta, R. C. (2013). Virulence analysis of Fusariumoxysporum f.sp. lycopersici causing tomato wilt in India. Journal of Mycology and Plant Pathology, 43, 409-413. Retrieved from http://www.connectjournals.com/.

Proestos, C., Chorianopoulos, N., Nychas, G. J., \& Komaitis, M. (2005). RPHPLC analysis of the phenolic compounds of plant extracts. Investigation of their antioxidant capacity and antimicrobial activity. Journal of Agricultural and Food Chemistry, 53, 1190-1195. Retrieved from https://pubs.acs.org/journal/jafcau

Putri, O. S. D., Sastrahidayat, I. R., \& Djauhari, S. (2014). Effect of Fusarium oxysporum f.sp. lycopersici (Sacc.) on Fusarium Wilt disease of Tomato (Lycopersicon esculentum Mill.). Journal of HPT, 2 (3), 74-81. Retrieved from http://jurnalhpt.ub.ac.id/index.php/jhpt

Riansyah, Y., Mulqie, L., \& Choesrina, L. (2015). Antiinflamation activity examination of sweet potato leaf ethanol extract on wistar rat male. Research Report, University of Islam Bandung.

Saputri, D. D. (2018). Antifungal activity of purple sweet potato (Ipomoea batatas L.) leaf extract against Fusarium oxysporum. Pedagogia Journal, 10 (1), 84-91.

Saputri, D. D., \& Kurniasih, S. (2018). Phytochemical screening and analysis of Gass Cromatography - Mass Spectrometer (GCMS) ethanol extract of purple sweet potato (Ipomoea batatas L.) Leaves. Research Report. Bogor, University of Pakuan.

Setyaningsih. I., Desniar., \& Purnamasari, E. (2012). Antimicrobes of Chaetoceros gracilis which are cultivated with different light. Akuatika Journal, 3 (2), 183.Retrieved from http://jurnal.unpad.ac.id/akuatika
Soekarno., Bonny, P. W., Surono., \& Marhaenis, E. (2012). Potency of kangkung extract as biofungicide to control Fusarium Fruit rot disease in tomato. Fitopatologi Journal, 8 (5), 121127.Retrieved from https://journal.ipb.ac.id/index.php/jfiti

Sulastri., Erildawati., Syahrial., Nazar, M., \& Andayani, T. (2013). Antioxidant activity of ethanol extract of purple sweet potato (Ipomoea batatas L.) leaves from saree, aceh cultivation. Journal of Chemical and Environtmental Engineering, 9 (3), 126-131.Retrieved from https://www.sciencedirect.com/journal/journal-of-environmental-chemical-engineering

Tando, E. (2018). Potential of secondary metabolite compounds in Soursop (Annona murricata) and Srikaya (Annona squamosa) as vegetable pesticides for control of pests and disease in plants. Biotropika Journal, 6 (1), 21-27. Retrieved from https://biotropika.ub.ac.id/index.php/biotropika

Utami, A. W. A. (2018). Isolation and identification of fungi causing withered disease in cayenne pepper (Capsicum frutescens) Plants in Bogor. Pedagogia Journal, 10 (1), 34-43. Retrieved from https://repository.unpak.ac.id/index.php?p=detail\&id karya=171.

Wen, H., Kang, J., Li, D., Wen, W., Yang, F., Hu. H., \& Liu, C. (2016). Antifungal activities of anthocyanins from purple sweet potato in the presence of food preservatives. Food science and biotechnology, 25(1): 165-171. DOI:10.1007/s10068016-0025-7

Wongpia, A., \& Lomthaisong, K. (2010). Changes in the 2DE protein profiles of chilli pepper (Capsicum annuum L.) leaves in response to Fusarium oxysporum infection. Science Asia, 36, 259-270.Retrieved from $\underline{\text { ttp://www.scienceasia.org/ }}$ 